Why Do Protest, Lobbying, and Other Forms of Advocacy Often Fail to Affect Policy?

Some Possible Explanations

Paul Burstein

Department of Sociology, University of Washington, Seattle

burstein@uw.edu

Paper to be presented at the annual meeting of the American Political Science Association, 2020

running head: advocacy and policy

key words: social movement organizations, interest groups, protest, lobbying, advocacy, public policy 


\title{
Why Do Protest, Lobbying, and Other Forms of Advocacy Often Fail to Affect Policy? Some Possible Explanations
}

\begin{abstract}
:
Researchers asking whether policy is affected by social movement organizations, interest groups, and other types of advocacy organizations usually expect the answer to be yes. More often than not, their expectations are disappointed. This paper considers why, considering whether the impact of advocacy is affected by which issues and polities are studied, how advocacy and policy are measured, the amount of advocacy, status quo bias, and the connection between advocacy and public opinion. Through a research synthesis of work on advocacy and policy, the paper finds that estimates of impact are probably affected by measurement, the paucity of advocacy on many issues, and whether public opinion is considered together with advocacy; but probably not by the selection of issues and polities or status quo bias. The findings lead to suggestions for improvements in research design that would enhance our understanding of the links between advocacy and policy.
\end{abstract}




\section{Why Do Protest, Lobbying, and Other Forms of Advocacy Often Fail to Affect Policy? Some Possible Explanations}

Researchers who ask whether social movement organizations (SMOs) and protest affect policy nearly always expect the answer to be yes; predictions of no impact are rare (Burstein 2019, 13). The same is true with regard to interest groups, lobbying, and other types of organizations (such as NGOs) and activities--collectively, advocacy organizations and activities, or just advocacy. More often than not, however, these expectations are not fulfilled. At least in quantitative work, advocacy organizations and activities affect policy less than half the time (Burstein 2019; 2020a).

The gap between expectations and findings has been noted before (e.g., Amenta et al. 2010; Grossman and Pyle 2013, 95; Leech 2010; Lowery 2013; Olzak and Soule 2009, 201), and is a matter of real concern. "Why," Leech writes $(2010,534)$, "when politicians, the public, and most other political scientists all are convinced that interest groups are so powerful, is it so hard for interest group scholars to pin down this relationship?" "It is worth discussing," Amenta et al. $(2010,294)$ write, "why so often research finds that movements exhibit little or no influence." Efforts to explain why advocacy is often ineffective generally proceed in two ways-authors' attempts to explain their own findings, and broad overviews of work on advocacy (e.g., Amenta et al. 2010; Leech 2010; Lowery 2013). But both have significant limitations. Authors explaining their own findings seldom address advocacy's lack of impact more generally (Burstein 2019; 2020a), while broad overviews provide little evidence to support their arguments about why advocacy fails.

This paper addresses the gap between expectations and findings a third way-by 
systematically analyzing recent work on the impact of advocacy and testing hypotheses about why it is often ineffective. It is a "research synthesis" (Cooper, Hedges, and Valentine 2019)-a quantitative analysis of key elements of articles on advocacy and policy published in high-impact sociology and political science journals (Bunea and Baumgartner [2014] and Burstein [2019; 2020a; 2020b] provide examples; see also Amenta et al. 2010; Hojnacki et al. 2012). In addition to adopting a different approach, the paper intends to improve on past analyses in three ways. First, while previous overviews focus on particular types of advocacy (by social movements in Amenta et al. [2010], interest groups and lobbying in Leech [2010] and Lowery [2013]), this paper analyzes all types together. Second, this paper assesses impact not only in terms of statistical significance, but in terms of magnitude as well. And finally, this paper considers the impact of advocacy on policy at two levels-first, summarizing the findings from individual studies, and, second, considering how the overall pattern of findings may have been affected by decisions about research design. For example, if researchers use measures of advocacy especially unlikely to influence policy-and they there is evidence that they do (Burstein 2020b)-it may be their choice of measures that leads to their so often finding advocacy having no impact.

This paper considers whether findings about the impact of advocacy on policy are affected by: (1) which issues and polities are studied; (2) how advocacy and policy are measured; (3) how much advocacy there is; (4) status quo bias, meaning ways in which political institutions are structured so as to make change difficult; and (5) the impact of public opinion on policy.

The paper shows that conclusions about the impact of advocacy are probably affected by how advocacy and policy are measured, the paucity of advocacy on many issues, and whether public opinion is included in the analysis; but probably not by which issues and polities are 
studied or by status quo bias. It also highlights how seldom we ask how strongly advocacy affects policy. The paper concludes with suggestions for improving research on how advocacy affects policy.

\section{Issues in the Study of the Impact of Advocacy on Policy}

\section{How Strongly Does Advocacy Affect Policy?}

Researchers interested in the impact of advocacy surely want to know how strongly it affects policy. Do lobbyists affect policy powerfully, or just a little (Leech 2010)? Does protest lead to big shifts in policy, or small ones (Giugni 1998)? Magnitudes matter (Firebaugh 2008, ch. 2). Yet researchers often describe findings only in terms of statistical significance (McShane et al. 2019; Ziliak and McCloskey 2008). Is that true of publications about the impact of advocacy on policy?

\section{Does the Impact of Advocacy Vary by Issue and Type of Polity?}

Leech (2010:540) writes that we have an exaggerated sense of how often advocacy influences policy because we focus on issues where impact is especially likely--issues characterized by a lot of advocacy and recent or impending policy change. We study environmental policy, for example, after the environmental movement has become "one of the most successful social movements of the $20^{\text {th }}$ century" (Agnone 2007:1593), local immigration policy after "a wave of local immigration laws ... swept across the country" (Steil and Vasi 2014:1105), and global changes in human rights policies in a "...world saturated with human rights organizations..." (Koo and Ramirez 2009:1321). 
Lowery (2013:15) agrees that our selection of issues influences our findings, but, in contrast to Leech, argues that on the high-activity issues we so often study, advocacy is especially unlikely to affect policy-public opinion will be more important.

Anzia (2019) makes a similar argument about polities we study. She contends that studies focus disproportionately on the federal government, which is relatively impervious to interest group influence, and pay less attention to state governments, which are supposedly more susceptible. We therefore find advocacy having little impact.

Hypothetically, studying a wider range of issues and polities would shift our findings about the impact of advocacy. Is this true? Systematically analyzing findings across a wide range of issues and politis should enable us to find out.

\section{Is the Apparent Impact of Advocacy Influenced by Measurement?}

Researchers who study the impact of public opinion on policy regularly consider how measurement may affect their findings. Measures of opinion vary in specificity, ranging from particular policies (e.g., Gilens and Page 2014), to action in broad policy domains (Soroka and Wlezien 2010), and policies across a wide range of issues in multiple domains (Erikson, MacKuen, and Stimson 2002; for general discussions, see Berinsky 2017; Druckman 2014; Larsen 2019); measures of policy vary similarly. Levels of specificity matter because they may affect findings--opinion has the strongest impact when very broad measures are used (Erikson, MacKuen and Stimson 2002; Erikson, Wright, and McIver 1993), a fairly substantial impact within policy domains (Soroka and Wlezien 2010), and, arguably, the weakest impact with regard to specific policies (Gilens and Page 2014), though some would disagree (e.g., Lax and 
Phillips 2009; 2012). It is taken for granted that when the impact of opinion on policy is estimated, they should be at the same level of specificity (Lewis and Jacobsmeier 2017; Nicholson-Crotty, Peterson, and Ramirez 2009).

Measures in the study of advocacy and policy vary similarly. There are measures of advocacy targeting specific policies (e.g., Best 2012), policies in broad policy domains (Johnson, Agnone, and McCarthy 2010; Santoro 2002), and policies across multiple domains (Bailey 2015; Bearce 2003); some measures, such as the number of organizations interested in an issue, focus more on potential advocacy than advocacy activities (e.g., Boix 2000; Boyle, Kim, and Longhofer 2015; Negro, Perretti, and Carroll 2013). Measures of policy similarly range from the very specific (Kane 2003) to the very broad (Bailey 2015). In contrast to those studying opinion and policy, however, researchers studying advocacy and policy rarely discuss levels of specificity or the possible utility of matching independent and dependent variables. Yet a good argument can be made that they should. It is relatively easy to imagine how advocacy targeting a specific policy could influence enactment of that policy-for example, how lobbying for funding for research on particular diseases would affect congressional action on such funding. When multiple policies are involved, however, the process may be less straightforward. How might protests pertaining to "the environment" affect action on any particular policy proposal (e.g., Johnson, Agnone, and McCarthy 2010)? Would it affect all proposals the same way? That's far from clear. When the dependent variable is the product of many policies enacted over varying periods of time-for example, social welfare expenditures (e.g., Hooghe and Oser 2016)-it becomes even more difficult to see how lobbying or protest on specific issues (unemployment, pensions, welfare, etc.) at particular times affect such a broad outcome. It seems reasonable to hypothesize 
that advocacy will most likely matter when the independent and dependent variables pertain to a specific policy, and less likely when the independent variable is less targeted and the dependent variable is more complex (Burstein 2014; 2020b).

\section{Might There Be Too Little Advocacy to Influence Policy?}

In The Logic of Collective Action, Olson (1971) made a convincing argument that he immediately concluded must be flawed. The disincentives to collective action were such, he contended, that there would be very little. Yet there seemed to be a lot-there were many organizations trying to influence policy. The disjuncture between what he expected and what he observed led him to elaborate on his argument, specifying when collective action might flourish.

But his original argument may have better than he thought. He thought the existence of thousands of organizations lobbying the federal government meant that people were considerably more likely to engage in collective action than he first believed. But had Olson taken the size of the American population into account, he might have concluded that the proportion of people engaging in collective action was as small as his theory suggested. And there is evidence that there is little advocacy on most issues-little lobbying (Baumgartner and Leech 2001), little money spent on lobbying (Mahoney and Baumgartner 2015), little advocacy, broadly defined (Burstein 2014), little advocacy found in studies of specific policies (Burstein and Sausner 2005), little money contributed to campaigns (Ansolabehere, de Figueiredo, and Snyder 2003). Might we hypothesize that advocacy regularly fails to influence policy because there is so little of it? 


\section{Does Status Quo Bias Hinder Advocacy?}

It has been argued that conflict between those favoring the status quo and those favoring policy change does not occur on the proverbial level playing field. Those favoring the status quo begin with many advantages-likely stability in the balance of forces that produced the status quo, the difficulty of getting policymakers' attention, the number of veto points at which proposals may be blocked, and how easily doubts may be raised about new proposals in the minds of risk-averse legislators. All these forces are behind what Baumgartner et al. (2009: 241) call "undoubtedly, the most consistent finding throughout our book" about lobbying in the U.S. Congress, namely, "defenders of the status quo usually get what they want: no change." McKay (2012), too, finds status quo bias; lobbying Congress against policy change is much more effective than lobbying for change (McKay 2012). But is status quo bias important generally, not just with regard to lobbying in Congress? Lowery (2013:12) thinks so; he writes that the "power of the status quo" is such that for lobbyists seeking change, successes are likely to be "rare." Is that what we find when we examine the power of the status quo for other forms of advocacy in other venues?

\section{Advocacy and Public Opinion: Opposition or Mutual Reinforcement?}

Gilens and Page's (2014) article, "Testing Theories of American Politics," is a model of theorytesting research in the study of democratic politics. The questions they address-“"Who governs? Who really rules?" (p. 564)-are fundamental to our concerns about democracy. Their alternatives-average citizens, economic elites, and mass-based or business-oriented interest groups-have been central to research for decades.

What they find comes down squarely on one side of a long debate. Economic elites and 
interest groups influence policy, but average American's preferences do not-their impact is "near-zero" (Gilens and Page 2014, 575; see also Page and Gilens 2017, 135). Achen and Bartels $(2016,1)$ agree; the claim that "what the majority wants becomes government policy" is nothing more than a "folk theory" of democracy, "severely undercut by a growing body of scientific evidence."

Yet there are competing views. Caughey and Warshaw $(2018,263)$ show that policymaking in American states, 1936-2014, responded to public opinion. Lax and Phillips $(2009 ; 2012)$ show that both interest groups and public opinion influence policy. And not only may advocacy and public opinion affect policy independently, they may interact as well, each enhancing the effect of the other (see Kluver and Pickup 2019, Lax and Phillips 2012, and Rasmussen, Mader, and Reher 2018 on interest groups and public opinion, and Agnone 2007 and Giugni 1998 on protest and public opinion). There are competing hypotheses here: advocacy, perhaps especially advocacy by interest groups, may affect policy much more strongly than public opinion does; both advocacy and opinion may have significant, independent effects; or advocacy and opinion may not only affect policy independently, but interact as well.

\section{Analyzing Research on the Impact of Advocacy on Policy}

The goal here is to analyze key elements of what recent publications tell us about the impact of advocacy on policy. To do so, it is necessary to decide which types of advocacy should be included. Which publications-articles in refereed journals, books, or both? In which disciplines? How should the search be conducted?

There are nine analyses roughly comparable to this one, in that they analyze quantitatively 
an array of publications about advocacy and policy: three focus on interest groups and lobbying (Baumgartner and Leech 1998; Bunea and Baumgartner 2014; Hojnacki et al. 2012), one on social movements (Amenta, et al. 2010), two on interest groups and SMOs (Burstein and Linton 2002; Uba 2009), and three on advocacy broadly defined (Burstein 2019, 2020a, 2020b). Should the focus here be narrow-only interest groups or SMOs, for example--intermediate, including both interest groups and SMOs, or broad, including all types of advocacy organizations and activities? Burstein $(2019 ; 2020 \mathrm{a})$ argues that there are two reasons for adopting a broad focus. First, in recent work, neither articles analyzing the impact of advocacy on policy, nor theories attempting to explain it, provide any justification for focusing only on SMOs, interest groups, or other specific types of organizations (Burstein 2019, 5; 2020a, 4-7). Second, researchers analyzing the impact of advocacy often do not think of themselves as focusing on SMOs or interest groups; instead, at least half the time (Burstein and Linton 2002, 392; Burstein 2019, 11), they describe the organizations and activities they study in other ways-abstractly, as organized interests, interest organizations, NGOs, etc.; more concretely, as businesses, churches, unions, and the like; and as specific organizations, such as the ACLU or the National Association of Manufacturers. Thus, there do not seem to be good explicit arguments against adopting a broad focus, and a good argument for doing so-a narrower focus would exclude a great deal of work on the impact of advocacy. This paper therefore adopts Burstein's broad approach.

One of the nine analyses of advocacy includes both articles and books (Hojnacki et al. 2012), the rest only articles. Bunea and Baumgartner (2014:1415) explain why (Baumgartner, as a co-author of Hojnacki et al. 2012, is the only author who has analyzed both): focusing on articles keeps data collection manageable and helps ensure data quality, and articles are (on 
average) more likely to have a substantial impact (in terms of citation counts, for example). So it is articles that will be analyzed here.

In which disciplines? Two previous analyses address publications in one discipline (Amenta et al. 2010; Hojnacki et al. 2012), and the others in two-sociology and political science (Burstein 2019, 2020a, 2020b; Burstein and Linton 2002; Uba 2009), political science and economics (Baumgartner and Leech 1998), and political science and public policy (Bunea and Baumgartner 2014). This paper, too, focuses on sociology and political science.

How to conduct the search for relevant articles? All previous analyses of journal articles searched only in what are described as "major" or "high-impact" journals, and this paper will do so as well. The search here, like that of Burstein $(2019,7)$, but covering a longer time span, began with 20 highest-impact sociology journals and 15 highest-impact political science journals as of 2016, plus two specialty journals, Mobilization, which concentrates on social movements, and Interest Groups \& Advocacy, which concentrates on interest groups. A number of journals (especially in sociology) were then excluded because they rarely, if ever, publish articles on the determinants of policy. The journals actually searched included nine high-impact journals in sociology (American Journal of Sociology, American Sociological Review, European Sociological Review, Gender \& Society, Journal of Marriage and Family, Population and Development Review, Social Forces, Socio-Economic Review, and Sociology of Education) and 14 in political science (American Journal of Political Science, American Political Science Review, British Journal of Political Science, European Journal of Political Research, International Organization, Journal of Conflict Resolution, Journal of European Public Policy, Perspectives on Politics, Political Analysis, Political Psychology, Public Administration, 
Regulation \& Governance, the Review of International Political Economy, and World Politics), plus Mobilization and Interest Groups \& Advocacy, for a total of 25, including both American and European journals. No other previous analysis covers more, except possibly Baumgartner and Leech (1998). The search of the journals was conducted by reading the table of contents of every issue from 2000 through 2018, and then, when necessary, abstracts and entire articles.

An alternative approach would have been to search more widely in a major database, seeking articles with key words, such as "policy" and various types of advocacy. An effort to do so proved problematic, however. As noted, researchers describe the organizations they study in a great variety of ways. A search using standard key words could miss half the articles estimating the impact of advocacy on policy (Burstein 2019, 11).

To be included, an article had to present statistical estimates of the impact of advocacy on policy. While it would be desirable, in the abstract, to include qualitative work, it is not feasible. Previous work has shown that it is impossible to confidently code authors' conclusions about impact in qualitative studies (Burstein 2019, 8), and, indeed, none of the other works on the impact of advocacy attempts to do so.

The dependent variable--the aspect of policy that advocates may influence--involved the final stage, or something close to it, of a legislature's or administrative agency's decisions about a proposed policy, focusing on specific policymaking actions. These actions include, for example, enacting legislation on medical research (Best 2012) and gun control (Steidley 2018) in the U.S.; adoption internationally of laws on abortion and human rights (Boyle, Kim, and Longhofer 2015; Koo and Ramirez 2009); social welfare policies in OECD countries (Jensen 2012); and action on policy proposals across a wide range of issues in the United States (Gilens 
and Page 2014).

The search discovered 72 articles, identified by asterisks in the list of references -47 in sociology and 25 in political science. The fact that most of the articles were in sociology journals may surprise some readers (especially given that 14 journals in political science were searched, but only nine in sociology), but is not a product of the search procedure; a somewhat similar search for articles published from 1990 through 2000 found the reverse--more in political science than in sociology (Burstein and Linton 2002). There is no claim here that the search for articles was comprehensive or that the articles are a random sample in any sense; the search simply goes beyond past work by including more types of advocacy than other analyses (except for Burstein's work) and analyzing its impact in much greater detail.

Hypotheses that advocacy has an impact were seen as supported by the data if the relevant coefficient was described as significant at the .05 level. Reliance on significance tests is sometimes seen as problematic, but they are the most practical and widely used method for comparing the findings of different studies. Meta-analysis was not feasible because relevant articles varied so widely in research design.

The way to code certain variables, such as the polities studied, is readily apparent, but the coding of others must be spelled out. A key guideline was that coding should reflect authors' views. For example, when the impact of advocacy is described as small or large, the assessment of magnitude is the authors'. Similarly, statistical relationships are described using the causal language authors use--in terms of "impact," "influence," or other, similar terms. The one exception to this rule is analyzing together-as advocacy--all the organizations and activities seen as potentially influencing policy, regardless of how authors describe them. 


\section{Findings}

\section{The Setting}

The 72 articles focus on the U.S. and on recent times. The U.S. was the subject of 46 articles- 18 on the federal government, 22 on state governments, and 6 on counties or municipalities. Sixteen focused on multiple OECD or EU countries-13 at the national level, and 3 on subnational political units. Two analyzed policy in other specific countries, one at the national level (Uba 2005 on India) and one at the subnational level (Hecock 2006 on Mexican states). Eight analyzed many countries worldwide (Boyle, Kim, and Longhofer 2015; Frank, Camp, and Boutcher 2010; Frank and Moss 2017; Grzymala-Buss 2016; Koo and Ramirez 2009; Longhofer et al. 2016; Simmons, Lloyd, and Stewart 2018; Velasco 2018). Eleven analyzed policy during the $21^{\text {st }}$ century; 24 included data beginning 1975 to 1999; 22 data beginning 1950 to 1974; 11, the first half of the $20^{\text {th }}$ century; 3 , the $19^{\text {th }}$ century; and 1 , the $18^{\text {th }}$.

\section{How Strongly Advocacy Affects Policy}

The 72 articles include 330 estimates of the impact of advocacy on policy. Of the coefficients, 138 (42 percent) were statistically significant, as predicted; 15 (five percent) were not statistically significant, as predicted. A majority-177, or 54 percent--were expected to be statistically significant and of a particular sign, but were not. This may seem surprising, given the bias against publishing negative findings, but all studies included positive as well as negative findings. Of course, no one expects that findings will always confirm expectations; original research necessarily steps into the unknown. Nevertheless, probably few researchers begin their 
work expecting to be wrong as often as they are right, and few funders would support researchers who did.

Few researchers described how strongly advocacy affects policy; 301 coefficients were described in the text only in terms of statistical significance (table 1). Of the remaining 29, 13 were described quantitatively without any evaluation of the strength of the relationship; Best $(2012,787)$, for instance, writes that with regard to federal funding for research on particular diseases, "each $\$ 1,000$ spent on lobbying [was] associated with a $\$ 25,000$ increase in research funds...." Three coefficients were described as statistically significant but inconsequential-Lewis (2013, 220), for example, writing that "Increasing [lobbying] spending... by 1 standard deviation (nearly US\$10000) around the mean....only increases the probability of passage [in the Wisconsin state legislature] by 0.06 percent." And 13 coefficients were described as signifying that the impact of advocacy was substantial, Lax and Phillips $(2012,163)$, for instance, writing that “...the interest group environment matters a great deal.... A liberal (conservative) interest group increases (decreases) the likelihood of having the liberal policy, all else equal, by up to $14 \%$.

table 1 here

A few authors present arguments and conclusions that implicitly assess magnitude. Page and Gilens (2014:566) write that according to theories of economic-elite domination, "U.S. policy making is dominated by individuals who have substantial economic resources" (emphasis added),and conclude that the impact of economic elites as "quite substantial" (p. 572). Soule and 
Olzak (2009:219) claim that "institutionalized forms of protest....have a powerful effect on the policy process."

All these assessments are plausible, but none has any context; authors interpret their own findings without comparing them to findings in other studies, or referring to any effort to establish standards for assessing the impact of advocacy. Gilens and Page say nothing about what it would mean to dominate policymaking or what the gap might be between dominating policymaking and having an impact that is quite substantial. Soule and Olzak say nothing about how to distinguish between an effect that is powerful and an effect that isn't.

\section{Issues and Polities}

As noted above, Leech (2010) contends that the impact of advocacy will be especially great on high-activity issues, while Lowery (2013) argues the reverse. There is no standard way to distinguish between high-activity issues and others. Here the categorization was implicitly arrived at by the authors themselves. When authors declare that the issues they are studying are especially controversial, or that huge numbers of people or organizations were trying to influence the relevant policies, or that there have been major changes in particular policies in many locations during a short time, the issues were classified as high-activity. Examples include environmental, immigration, and human rights policies, as noted above (Agnone 2007; Koo and Ramirez 2009; Steil and Vasi 2007), and also statements that "The rights of gays and lesbians... lie at the heart of recent political conflict in the United States" (Lax and Phillips 2009:367), the anti-Vietnam war movement was "one of the most significant...movements in recent U.S. history" (McAdam and Su 2002:697), and reference to "recent and dramatic increase in human 
trafficking's criminalization" (Simmons, Lloyd, and Stewart 2018:250). Other issues designated as high-activity include abortion, civil rights, the ERA, social welfare policies, government regulation of sexual behavior, tobacco use, gun control, and incarceration. Issues not classified as high-activity are categorized as "lower-activity," even if arguments could be made (by others) that they matter. Examples include medical research, international trade, monetary policy, land use, education, and civil liberties, the right of women to serve on juries, and abolition. Some researchers studied a wide range of issues or policy proposals of varying degrees of importance, such as a random sample of 98 policy issues (Hojnacki et al. 2015), all the bills introduced into the $106^{\text {th }}$ and $107^{\text {th }}$ U.S. congresses (Grossman and Pyle 2013), and 1,779 issues for which public opinion data were available (Gilens and Page 2014). These can serve as a baseline, providing some idea of what we'd find if we wanted to discover the impact of advocacy in general, not just with regard to specific issues studied one (or a handful) at a time.

As it turns out, advocacy on high-activity issues is neither more nor less likely to affect policy than advocacy on lower-activity issues, or on random samples, populations, or large samples of issues (table 2), for interest groups specifically and advocacy overall. This may surprise those agreeing with Leech or Lowery, but it's what we find in this first analysis of relevant data.

table 2 here

What about Anzia's (2019) claim that we underestimate the impact of advocacy because our studies neglect state governments, where it is especially likely to matter? If we consider 
advocacy in general, that is not what happens. U.S. states are studied more often than other polities, not less (table 3 ) and the differences in impact among polities are small. At least in this set of articles, findings about the impact of advocacy are not distorted by a disproportionate focus on some types of polities.

table 3 here

\section{Measurement}

None of the 72 articles discusses either specificity in the measurement of advocacy and policy or the possible utility of matching the independent and dependent variables. For this analysis, measures of advocacy are divided into three categories-resources, such as the number of advocacy organizations or the size of their budgets; advocacy intended to influence policy in a broad policy domain (but not specific policies), and advocacy directed at specific policies. Measures of policy are categorized in analogous fashion, from broad measures of welfare policy that incorporate many specific policies, to specific policy proposals arrayed across multiple policy domains, multiple proposals within the same domain, and specific policy proposals (table 4).

table 4 here

Researchers' approach to measurement may be seen as reflecting their practical 
concerns-they tend to use data that are relatively easy to obtain. Measures of policy are most often about specific proposals, which are the unit of analysis in official records; measures of advocacy most often gauge numbers of organizations and their resources, which are easier to obtain than data on organizations' advocacy activities.

Hypothetically, policymakers will be most strongly affected by activities directed at specific policies, and least strongly by measures of resources; advocacy should most often affect specific policies, and least often influence broad measures incorporating multiple policies.

This is what we find, in a general way. Table 4 is a two-dimensional summary of a threeway table-measures of advocacy by measures of policy by how often relationships between advocacy and policy are statistically significant. The upper left cell shows that 44 coefficients gauged the impact of measures of resources on combined measures of policy, and, of the 44, 52 percent were statistically significant. Moving to the right in the same row, there were 29 coefficients gauging the impact of resources on specific policies in multiple domains, and, of the 29, 52 percent (again) were statistically significant.

Table 4 shows that the least targeted measure of advocacy, namely resources, is most likely to affect the broadest measures of policy, and least likely to affect action on specific policy proposals (reading across the first row of the table). Advocacy affects policy most often (though by a very small margin) when advocacy for a specific proposal is connected to that specific proposal (second row from bottom, second column from the right). This makes sense in terms of how we view political action-policy is most likely to be affected by efforts intended to affect it. The result of researchers' decisions about how to measure advocacy and policy proves somewhat ironic, however: the most common way of examining the impact of advocacy-gauging the impact 
of resources on specific policy proposals-is least likely to find an effect (see Burstein [2020b] for comparable findings about a wider range of variables). Only an analysis like the present one could discover this and bring it to researchers' attention.

\section{How Much Advocacy}

The 72 articles include 57 instances in which advocacy activities (as opposed to organizational resources) were expected to influence policy, but didn't. Might advocacy have had no impact because there was so little of it? There are no standards for deciding how much activity is a little and how much is a lot. All we can do is describe how much there was and try to interpret the findings in a sensible way.

For 37 of the 57 coefficients, the articles provided data on how much advocacy there was. In ten instances, protest-environmental, anti-nuclear, pro-peace, and civil rights, all in the U.S.-had no impact. For these instances, the mean number of protests per year, for the entire country, never exceeded 16, and the maximum number, when available, never exceeded 75 . Thus, on most days there were no protests anywhere in the country, and probably in quite a few states there were no protests during entire years (Agnone 2007; Giugni 2007; McAdam and Su 2002; Olzak and Ryo 2007; Olzak 2016 ). Even if there were ten times as many protests as reported, the numbers seem small for a nation whose population averaged over 200 million during the periods covered by the studies.

Other types of advocacy seem similarly infrequent. Interest groups trying to influence legislation in Chile submitted an average of 3.1 comments per bill (Gamboa, Segovia, and Avendano 2016). The mean number of witnesses testifying before a congressional committee on 
behalf of funding for research on particular diseases was 0.4 (Best 2012). Proponents of U.S. women's right to serve on juries used arguments intended to influence state legislators 4.3 times per state per year (McCammon et al. 2007). The number of pro-immigrant marches aimed at influencing municipal ordinances in the U.S. between February and May of 2006 averaged between 0.12 and 2.2 per city (Steil and Vasi 2014). Of 37 instances in which advocacy was expected to influence policy, but didn't, 24 include levels of advocacy that seem too low to have any impact.

Other measures of advocacy are more difficult to interpret. Lobbyists spent an average of $\$ 3,500$ and 28.6 hours lobbying the Wisconsin state legislature on behalf of bills they were promoting, with maximums of $\$ 67,000$ and 685 hours (Lewis 2013). Applications for conscientious objector status during the Vietnam War, interpreted as a form of protest, averaged 2,850 per month, with a minimum of 1,616 and a maximum of 5,456 (McAdam and Su 2002, 708). Do those amounts of advocacy seem adequate to potentially influence policy? This is not something researchers seem to have thought about. But perhaps they should.

\section{Status Quo Bias}

The 72 articles provide no evidence of status quo bias-those favoring change are about as likely to get what they want as those favoring the status quo (table 5).

table 5 here 
Does this mean that Baumgartner et al.'s (2009) arguments are wrong? Not necessarily. The likelihood of finding status quo bias may depend in part on which issues we study, and when.

There is an important difference between Baumgartner et al.'s research design and the collective research design utilized in the 72 articles. Many of the articles may be seen as having selected on the dependent variable (Leech 2010:540), selecting issues because policy change had begun or seemed imminent. Baumgartner et al. (2009, ch. 1), in contrast, studied a random sample of issues on which there was lobbying. Baumgartner et al. are bound to find policy change occurring much less often, and are therefore less likely to find advocacy having an impact.

\section{Public Opinion and Advocacy}

What can the 72 articles tell us about how advocacy and public opinion together affect policy? To begin, what they can tell us is limited. Only 18 articles consider the impact of both. They show us that we cannot say that advocacy generally overwhelms public opinion, or vice versa. Advocacy, but not opinion, affects policy in six articles (Chen 2007; Gilens and Page 2014; Grzymala-Busse 2016; Johnson, Agnone, and McCarthy 2010; McAdam and Su 2002; Soule and Olzak 2004); in three, opinion has an impact but not advocacy (Giugni 2007; Martin 2010; Soule and King 2006); and in eight, they both influence policy (Agnone 2007; Amenta, Caren, and Olasky 2005; Hildebrandt, Trudinger, and Jackle 2017; Kane 2003; Lax and Phillips 2009; 2012; Santoro 2002; Steidley 2018 ).

Beyond that, there is some support for the hypothesis that advocacy and opinion interact, 
each enhancing the effect of the other; three of the four articles examining such an interaction found that it mattered (Agnone 2007; Lax and Phillips 2009; Steidley 2018; Giugni [2007] found it did not). The fact that advocacy is slightly more likely to affect policy when public opinion is included (table 6; Burstein and Linton [2002:396] find the same thing) further suggests the possible utility of pursuing interaction effects. With 14 articles including both advocacy and opinion but not calculating the possible impact of an interaction between them, it could be possible to redo the statistical analysis, where data are still available. This would enable us to learn more about interaction effects without having to do more research.

table 6 here

For some of the articles that did not include public opinion, it might have been possible to do so, had the researchers wanted to. There are probably public opinion data available on social welfare spending, tax policy, tobacco use, and the environment in the U.S., the EU, and OECD countries-topics covered in a number of the articles (e.g., Bailey 2015; Gifford 2006; Gordon 2015; Hooghe and Oser 2016; Jacob and Helms 2011; Jensen 2012; Olzak et al. 2016; Studlar, Christensen, and Sitasari 2011; Zylan and Soule 2000). It should not be difficult to gauge the impact of both advocacy and opinion more often.

On many issues there will be no data for practical reasons-for example, polls are seldom conducted in some countries or at the municipal level (see, e.g., Boyle, Kim, and Longhofer 2015; Steil and Vasi 2014), and none were conducted before the 1930s (Budros 2011). For many 
issues, though, polling would not help, because most people are very unlikely to have opinions-for example, on most bills and administrative regulations (Grossman and Pyle 2013;

Haeder and Yackee 2015; Lewis 2013). On those issues, there would be no competition between advocacy and public opinion. It is worth noting that on many issues, there is little or no advocacy, and, on many, no meaningful public opinoin. It could be useful to consider how often policy proposals fail to win enactment, not because of status quo bias, but because there is neither advocacy nor public opinion favoring them (Burstein 2014; 2020c).

\section{Conclusions}

Researchers nearly always expect advocacy to influence policy, but, more often than not, it doesn't. What's more, researchers very seldom claim that advocacy's impact is substantial.

This paper has considered hypotheses as to why advocacy often fails to affect policy-the first paper to do so, so far as I know. The findings are necessarily preliminary, yet they do enhance what we know about the impact of advocacy.

Some factors hypothesized to affect the relationship between advocacy and policy really do so. Measurement matters. Resources most often affect broad measures of policy; advocacy is most likely to have an impact when it targets specific policy proposals. Resources are especially unlikely to affect specific policies, yet researchers focus on this relationship more often than any other-surely one reason advocacy so often seem to have no impact.

Researchers very seldom ask whether advocacy may fail to affect policy because there is so little of it. But they should; we find that sometimes when advocacy is expected to influence policy but doesn't, there was very little advocacy. 
Advocacy and public opinion are studied together relatively seldom, but that may be a mistake. Advocacy seems a bit more likely to affect policy when opinion is included in the analysis; what's more, there is some evidence that each may reinforce the effect of the other.

Other hypotheses were not supported by the data. The choice of neither issues nor polities seems to affect our findings, nor does status quo bias. Yet arguments that choice of issues and status quo bias should matter are so powerful that it is too soon to reject them. Finding that advocacy is not more likely to affect policy on high-activity issues seems especially unexpected. If advocacy fails to affect policy even on such issues, we must ask how limited the impact of advocacy might be.

These findings have a number of implications for future research. First, we might adjust our expectations. Expecting advocacy to affect policy should not be the default; more effort should be made to specify when it will and when it will not.

Second, we should pay more attention to measurement. We most often measure advocacy in terms of organizational resources, and policy in terms of specific policies, not for theoretical reasons, but because such data are easily obtained. If we focused more on advocacy targeting specific policies, we would find it more often having an impact and learn more about how advocacy works.

Third, our analyses should focus on how much advocacy there is as well as on estimates of its impact. Lack of impact could sometimes be explained by lack of advocacy.

Fourth, we should more often study the impact of advocacy and public opinion together, and consider whether each enhances the other's impact. When no public opinion data are available, we should distinguish between situations in which the reasons are practical (no surveys 
were done) and issues on which few people have meaningful opinions (Achen and Bartels 2016). Advocacy seems more likely to matter when there is no public opinion to compete with.

Fifth, we need to think about which issues to study. We pay a lot of attention to some issues (e.g., environmental policy, social welfare policies, and LGBT rights), and, at least in high-impact journals, much less to other much-debated policies (e.g., abortion, education, foreign affairs, health, infrastructure, trade, and taxes), and, almost none to the many relatively obscure issues found in random samples of issues and policy proposals (Baumgartner et al. 2009; Burstein 2014). Yet findings from random samples of issues are likely to differ considerably from the findings we're used to; in random samples, advocacy and opinion will affect policy much less frequently (Burstein 2020c).

Finally, it would be important to ascertain not only whether advocacy affects policy, but also how strongly. To do this meaningfully, it will be necessary not only to report magnitudes in specific studies, but to develop standardized ways to report magnitudes so that different studies can be compared. This is bound to be a very difficult task which, so far, no one has been willing to take up. Yet progress in studying advocacy is bound to be limited until someone does.

Some of these proposals could readily be implemented. Researchers could alter expectations by analyzing past work and finding out when expectations are met and when they aren't; data on how much advocacy there is are already available. Others, such as improving measurement, would require more work, but we already know how to do so. Still others might be more challenging. But pursuing any of these proposals would enhance the quality of our work on advocacy and policy, and enable us to better understand how the policy process works. 


\section{References}

Note: articles coded are designated *

Achen, Christopher H., and Larry M. Bartels. 2016. Democracy for Realists: Why Elections Do

Not Produce Responsive Government. Princeton: Princeton University Press.

*Agnone, Jon. 2007. “Amplifying Public Opinion: the Policy Impact of the U..S. Environmental Movement." Social Forces 85(4):1593-1620.

Amenta, Edwin, Neal Caren, Elizabeth Chiarello, and Yang Su. 2010. "The Political Consequences of Social Movements." Annual Review of Sociology 36:287-307.

*Amenta, Edwin, Neal Caren, and Sheera Joy Olasky. 2005. “Age for Leisure: Political Mediation and the Impact of the Pension Movement on U.S. Old-Age Policy." American Sociological Review 70(3):516-538.

*Amenta, Edwin, and Drew Halfmann. 2000. "Wage Wars: Institutional Politics, WPA Wages, and the Struggle for U.S. Social Policy.” American Sociological Review 65(4):506-528.

*Andrews, Kenneth T. 2001. "Social Movements and Policy Implementation: The Mississippi Civil Rights Movement and the War on Poverty, 1965 to 1971." American Sociological Review 66(1):71-95.

Ansolabehere, Stephen, John de Figueiredo, and James M. Snyder, Jr.. 2003. "Why Is There So Little Money in U.S. Politics?" Journal of Economic Perspectives 17(1):105-30.

Anzia, Sarah F. 2019. "Looking for Influence in All the Wrong Places: How Studying Subnational Policy Can Revive Research on Interest Groups." Journal of Politics 81(1):343-351.

*Bailey, David J. 2015. "Resistance Is Futile? The Impact of Disruptive Protest in the 'Silver 
Age of Permanent Austerity'." Socio-Economic Review 13(1):5-32.

Baumgartner, Frank, Jeffrey M. Berry, Marie Hojnacki, David C. Kimball, and Beth L. Leech. 2009. Lobbying and Policy Change: Who Wins, Who Loses, and Why. Chicago: University of Chicago Press.

Baumgartner, Frank R., and Beth L. Leech. 1998. Basic Interests. Princeton, NJ: Princeton University Press.

Baumgartner, Frank R., and Beth L. Leech. 2001. "Interest Niches and Policy Bandwagons: Patterns of Interest Group Involvement in National Politics." Journal of Politics 63(4):1191-1213.

*Bearce, David H. 2003. “Societal Preferences, Partisan Agents, and Monetary Policy Outcomes." International Organization 57 (2): 373-410.

Berinsky, Adam J. 2017. "Measuring Public Opinion with Surveys." Annual Review of Political Science 20:309-29.

*Bernhagen, Patrick, Andreas Dur, and David Marshall. 2014. Measuring lobbying success spatially. Interest Groups \& Advocacy 3(2):202-218.

*Best, Rachel Kahn. 2012. "Disease Politics and Medical Research Funding.” American Sociological Review 77:780-803.

*Boix, Carles. 2000. "Partisan Governments, the International Economy, and Macroeconomic Policies in Advanced Nations, 1960-93.” World Politics 53(1): 38-73.

*Boyle, Elizabeth H., Minzee Kim, and Wesley Longhofer. 2015. “Abortion Liberalization in World Society, 1960-2009.” American Journal of Sociology 121(3):882-913.

*Budros, Art. 2011. "Explaining the First Emancipation: Social Movements and Abolition in the 
U.S. North, 1776-1804." Mobilization 16(4):439-54.

Bunea, Adriana, and Frank R. Baumgartner. 2014. "The State of the Discipline: Authorship, Research Designs, and Citation Patterns in Studies of EU Interest Groups and Lobbying." Journal of European Public Policy 21(10):1412-1434.

Burstein, Paul. 2003. "The Impact of Public Opinion on Public Policy: a Review and an Agenda." Political Research Quarterly 56:29-40.

Burstein, Paul. 2014. American Public Opinion, Advocacy, and Policy in Congress: What the Public Wants and What It Gets. New York: Cambridge University Press.

Burstein, Paul. 2019. "The Influence of Organizations on Policy: Theories, Findings, Conclusions," Interest Groups \& Advocacy 8:1-22.

Burstein, Paul. 2020a. "Testing Theories about Advocacy and Public Policy." Perspectives on Politics DOI: https://doi.org/10.1017/S1537592719004663

Burstein, Paul. 2020b. "The Determinants of Public Policy: What Matters and How Much." Policy Studies Journal 48 (1):207-30.

Burstein, Paul. 2020c. "The Influence of Public Opinion and Advocacy on Public Policy: Controversies and Conclusions," Pp. 738-760 in The New Handbook of Political Sociology, edited by Thomas Janoski, Cedric de Leon, Joya Misra, and Isaac William Martin. New York: Cambridge University Press.

Burstein, Paul, and April Linton. 2002. "The Impact of Political Parties, Interest Groups, and Social Movement Organizations on Public Policy." Social Forces 81(2):380-408.

Burstein, Paul, and Sarah Sausner. 2005. "The Incidence and Impact of Policy-Oriented Collective Action: Competing Views." Sociological Forum 20:403-19. 
*Carpenter, Daniel P. 2002. “Groups, the Media, Agency Waiting Costs, and FDA Drug Approval.” American Journal of Political Science 46 (3):490-505.

Caughey, Devin, and Christopher Warshaw. 2018. "Policy Preferences and Policy Change: Dynamic Responsiveness in the American States, 1936-2014.” American Political Science Review 112(2):249-266.

*Chen, Anthony S. 2007. The party of Lincoln and the politics of state fair employment practices legislation in the north, 1945-1964. American Journal of Sociology 112:pp. 1713-1774.

Cooper, Harris, Larry V. Hedges, and Jeffrey C. Valentine. 2019. "Research Synthesis as a Scientific Process." In The Handbook of Research Synthesis and Meta-analysis, ${ }^{\text {rd }}$ edition, eds. Harris Cooper, Larry V. Hedges and Jeffrey C. Valentine, 3-16. New York: Russell Sage Foundation.

*Cornwall, Marie, Brayden G. King, Elizabeth M. Legerski, Eric C. Dahlin, and Kendra S. Schiffman. 2007. "Signals or Mixed Signals: Why Opportunities for Mobilization Are Opportunities for Policy Reform.” Mobilization 12(3):239-254.

Druckman, James N. 2014. "Pathologies of Studying Public Opinion, Political Opinion, and Democratic Responsiveness." Political Communication 31(3):467-492.

Erikson, Robert S., Michael B. MacKuen, and James A. Stimson. 2002. The Macro-Polity. New York: Cambridge Press.

Erikson, Robert S., Gerald C. Wright, and John P. McIver. 1993. Statehouse Democracy. New York: Cambridge University Press.

Firebaugh, Glenn. 2008. Seven Rules for Social Research. Princeton: Princeton University Press. *Frank, David J., Bayliss J. Camp and Steven A. Boutcher. 2010. "Worldwide Trends in the 
Criminal Regulation of Sex, 1945 to 2005." American Sociological Review 75:867-93.

*Frank, David John, and Dana M. Moss. 2017. "Cross-National and Longitudinal Variation in the Criminal Regulation of Sex, 1965 to 2005." Social Forces 95(3):941-969.

*Gawande, Kishore, and Bernard Hoekman. 2006. "Lobbying and Agricultural Trade Policy in the United States.” International Organization 60 (2):527-561.

*Gamboa, Richardo, Carolina Segovia, and Octavio Avendano. 2016. "Interest Groups and Policymaking: Evidence from Chile, 2006-2014.” Interest Groups \& Advocacy 5:141-64.

*Gerber, Elisabeth R., and Justin H. Phillips. 2003. "Development Ballot Measures, Interest Group Endorsements, and the Political Geography of Growth Preferences." American Journal of Political Science 47(4):625-39.

*Gifford, Brian. 2006. “Why No Trade-off Between 'Guns and Butter’? Armed Forces and Social Spending in the Advanced Industrial Democracies, 1960-1993.” American Journal of Sociology 112:473-509.

*Gilens, Martin, and Benjamin I. Page. 2014. "Testing Theories of American Politics: Elites, Interest Groups, and Average Citizens." Perspectives on Politics 12(3):564-81.

*Giugni, Marco. 2007. "Useless Protest? A Time-series Analysis of the Policy Outcomes of Ecology, Antinuclear, and Peace Movements in the United States, 1977-1995.” Mobilization 12(1):53-77.

Giugni, Marco. 1998. "Was It Worth the Effort? The Outcomes and Consequences of Social Movements." Annual Review of Sociology 24:371-393.

*Gordon, Joshua C. 2015. "Protecting the Unemployed: Varieties of Unionism and the Evolution of Unemployment Benefits and Active Labor Market Policy in the Rich Democracies." 
Socio-Economic Review 13(1):79-99.

*Grossmann, Matt, and Kurt Pyle. 2013. "Lobbying and Congressional Bill Advancement." Interest Groups \& Advocacy 2(1):91-111.

*Grzymala-Busse, Anna. 2016. "Weapons of the Meek How Churches Influence Public Policy." World Politics 68(1):1-36.

*Haeder, Simon F., and Susan Webb Yackee. 2015. "Influence and Administrative Process: Lobbying the U.S. President's Office of Management and Budget." American Political Science Review 109(3):507-22.

*Hecock, R. D. 2006. “Electoral Competition, Globalization, and Subnational Education Spending in Mexico, 1999-2004.” American Journal of Political Science 50:950-961.

*Hildebrandt, Achim, Eva-Maria Trudinger, and Sebastian Jackle. 2017. "Sooner or Later: The Influence of Public Opinion and Religiosity on the Enactment of Laws Recognizing Same-Sex Unions.” Journal of European Public Policy 24 (8):1191-1210.

Hojnacki, Marie, David C. Kimball, Frank R. Baumgartner, Jeffrey M. Berry, and Beth L. Leech. 2012. "Studying Organizational Advocacy and Influence: Reexamining Interest Group Research." Annual Review of Political Science 15:379-399.

*Hojnacki, Marie, Kathleen M. Marchetti, Frank R. Baumgartner, Jeffrey M. Berry, David C. Kimball, and Beth L. Leech. 2015. “Assessing Business Advantage in Washington Lobbying.” Interest Groups \& Advocacy 4(3):205-24.

*Hooghe, Marc, and Jennifer Oser. 2016. "Trade Union Density and Social Expenditure: A Longitudinal Analysis of Policy Feedback Effects in OECD Countries, 1980-2010.” Journal of European Public Policy 23(10):1520-1542. 
*Ingram, Paul, and Hayagreeva Rao. 2004. "Store Wars: The Enactment and Repeal of AntiChain-Store Legislation in America." American Journal of Sociology 110(2):446-487.

*Jacobs, David, and Ronald Helms. 2001. "Racial Politics and Redistribution: Isolating the Contingent Influence of Civil Rights, Riots, and Crime on Tax Progressivity.” Social Forces 80(1): 91-121.

*Jenkins, J.Craig, KevinT. Leicht and Heather Wendt. 2006. "Class Forces, Political Institutions, and State Intervention: Subnational Economic Development Policy in the United States, 1971-1990.” American Journal of Sociology 111:1122-1180.

*Jensen, Carsten. 2012. "Two Sides of the Same Coin? Left-wing Governments and Labour Unions as Determinants of Public Spending.” Socio-Economic Review 10 (2):217-40.

*Johnson, Erik W. 2008. "Social Movement Size, Organizational Diversity and the Making of Federal Law." Social Forces 86(3):1-28.

*Johnson, Erik W., Jon Agnone, and John D. McCarthy. 2010. “Movement Organizations, Synergistic Tactics, and Environmental Public Policy." Social Forces 88(4):2267-92.

*Kane, Melinda. 2003. "Social Movement Policy Success: Decriminalizing State Sodomy Laws 1969-1998." Mobilization 8(3):313-334.

*Kaya, Cansarp. 2018. "The Impact of Interest Group Diversity on Legal Implementation in the European Union.” Journal of European Public Policy 25(4):567-585.

*King, B., Cornwall, M., \& Dahlin, E. (2005). "Winning Woman Suffrage One Step at a Time: Social Movements and the Logic of the Legislative Process." Social Forces 83(3), 1211-1234.

Kluver, Heike. 2012. "Informational Lobbying in the European Union: The Effect of 
Organisational Characteristics.” West European Politics 35(3):491-510.

Klüver, Heike, and Mark Pickup. 2019. “Are They Listening? Public Opinion, Interest Groups and Government Responsiveness.” West European Politics 42(1): 91-112.

*Koo, Jeong-Woo, and Francisco O. Ramirez. 2009. "National Incorporation of Global Human Rights: Worldwide Expansion of National Human Rights Institutions, 1966-2004.” Social Forces 87(3):1321-1353.

Larsen, Erik Gahner. 2019. "Policy Feedback Effects on Mass Publics: A Quantitative Review." Policy Studies Journal 47(2):372-394.

*Lax, Jeffrey R. and Justin H. Phillips. 2009. "Gay Rights in the States: Public Opinion and Policy Responsiveness.” American Political Science Review 103:367.

*Lax, Jeffrey R., and Justin H. Phillips. 2012. "The Democratic Deficit in the States.” American Journal of Political Science 56:148-66.

Leech, Beth. 2010. "Lobbying and Influence." In The Oxford Handbook of American Political Parties and Interest Groups, eds.Sandy L. Maisel, Jeffrey M. Berry, and George C. Edwards, 696-719. New York: Oxford University Press.

*Lewis, Daniel C. 2013. “Advocacy and Influence: Lobbying and Legislative Outcomes in Wisconsin.” Interest Groups \& Advocacy 2(2):206-26.

Lewis, Daniel C., and Matthew L. Jacobsmeier. 2017. "Evaluating Policy Representation with Dynamic MRP Estimates: Direct Democracy and Same-Sex Relationship Policies in the United States." State Politics \& Policy Quarterly 17(4):441-64.

*Longhofer, Wesley, Evan Schofer, Natasha Miric, and David John Frank. 2016. "NGOs, INGOs, and Environmental Policy Reform, 1970-2010.” Social Forces 94(4):1743-1768. 
Lowery, David. 2013. "Lobbying Influence: Meaning, Measurement, and Missing." Interest Groups \& Advocacy 2(1):1-26.

Mahoney, Christine, and Frank R. Baumgartner. 2015. "Partners in Advocacy: Lobbyists and Government Officials in Washington. Journal of Politics 77(1):202-215.

*Martin, Isaac William. 2010. "Redistributing Toward the Rich: Strategic Policy Crafting in the Campaign to Repeal the Sixteenth Amendment, 1938-1958." American Journal of Sociology 116:pp. 1-52.

*McAdam, Doug, and Yang Su. 2002. "The War at Home: Antiwar Protests and Congressional Voting, 1965 to 1973.” American Sociological Review 67(5):696-721.

*McCammon, Holly. 2009. "Beyond Frame Resonance: the Argumentative Structure and Persuasive Capacity of Twentieth-century U.s. Women's Jury-rights Frames.” Mobilization 14(1):45-64.

*McCammon, Holly J., Karen E. Campbell, Ellen Granberg, and Christine Mowery. 2001. “How Movements Win: Gendered Opportunity Structures and the U.S. Women’s Suffrage Movements, 1866 to 1919.” American Sociological Review 66(1):49-70.

*McCammon, Holly J., Courtney S. Muse, Harmony D. Newman and Teresa M. Terrell. 2007. “Movement Framing and Discursive Opportunity Structures.” American Sociological Review 72:725-49.

McKay, Amy. 2012. "Negative Lobbying and Policy Outcomes.” American Politics Research 40(1):116-146.

McShane, Blakeley B., David Gal, Andrew Gelman, Christian Robert, and Jennifer L. Tackette. 2019. "Abandon Statistical Significance." American Statistician 73(S1):235-245. 
*Negro, Giacomo, Fabrizio Perretti, and Glenn R. Carroll. 2013. "Challenger Groups, Commercial Organizations, and Policy Enactment: Local Lesbian/gay Rights Ordinances in the United States from 1972 to 2008." American Journal of Sociology 119(3):790-832.

Nicholson-Crotty, Sean, David A.M. Peterson, and Mark D. Ramirez. 2009. "Dynamic Representation(s): Federal Criminal Justice Policy and Alternative Dimensions of Public Mood." Political Behavior 31(4):629-655.

Olson, Mancur. 1971. The Logic of Collective Action. Cambridge: Harvard University Press.

*Olzak, Susan, Sarah A. Soule, Marion Coddou, and John Munoz. 2016. "Friends or Foes: How Social Movement Allies Affect the Passage of Legislation in the U.S. Congress." Mobilization 21(2):213-30.

*Olzak, Susan, and Emily Ryo. 2007. "Organizational Diversity, Vitality, and Outcomes in the Civil Rights Movement.” Social Forces 85(4):1561-1591.

*Olzak, Susan, and Sarah A. Soule. 2009. "Cross-cutting Influences of Environmental Protest and Legislation.” Social Forces 88(1):201-226.

Page, Benjamin I., and Martin Gilens. 2017. Democracy in America? What Has Gone Wrong and What We Can Do About It. Chicago: University of Chicago Press.

Rasmussen, Anne, Lars Kai Mader, and Stefanie Reher. 2018. "With a Little Help from the People? The Role of Public Opinion in Advocacy Success." Comparative Political Studies 51(2):139-64.

*Santoro, Wayne A. 2002. "The Civil Rights Movement's Struggle for Fair Employment: A ‘Dramatic Events-Conventional Politics’ Model.” Social Forces 81(1): 177-206.

*Santoro, Wayne A. 2008. "The Civil Rights Movement and the Right to Vote." Social Forces 
86:1391-1414.

*Scheitle, Christopher P., and Bryanna B. Hahn. 2011. "From Pews to Policy: Specifying Evangelical Protestantism's Influence on States' Sexual Orientation Policies.” Social Forces 89(3):913-934.

*Shipan, Charles R. and Craig Volden. 2006. "Bottom-up Federalism: the Diffusion of Antismoking Policies from U.S. Cities to States." American Journal of Political Science 50(4): 825-843.

*Shipan, Charles R., and Craig Volden. 2008. "The Mechanisms of Policy Diffusion.” American Journal of Political Science 52(4):840-857.

*Simmons, Beth A., Paulette Lloyd, and Brandon M. Stewart. 2018. "The Global Diffusion of Law: Transnational Crime and the Case of Human Trafficking." International Organization 72(spring):249-81.

*Sorensen, Rune J. 2003. "The Political Economy of Intergovernmental Grants: the Norwegian Case.” European Journal of Political Research 42:163-195.

Soroka, Stuart N., and Christopher Wlezien. 2010. Degrees of Democracy: Politics, Public Opinion, and Policy. New York: Cambridge University Press.

*Soule, Sarah A. and Brayden G. King. 2006. "The Stages of the Policy Process and the Equal Rights Amendment, 1972-1982.” American Journal of Sociology 111:1871-1909.

*Soule, Sarah A., and Susan Olzak. 2004. "When Do Movements Matter? The Politics of Contingency and the Equal Rights Amendment." American Sociological Review 69(4):473-97.

*Steidley, Trent. 2018. "Big Guns or Big Talk? How the National Rifle Association Matters for 
Conceal Carry Weapons Laws.” Mobilization 23(1):101-125.

*Steil, Justin Peter, and Ion Bogdan Vasi. 2014. "The New Immigration Contestation: Social Movements and Local Immigration Policy Making in the United States, 2000-2011.” American Journal of Sociology 119(4):1104-1155.

*Studlar, Donley T., Kyle Christensen, and Arnita Sitasari. 2011. "Tobacco Control in the EU15: the Role of Member States and the European Union.” Journal of European Public Policy 18(5):728-745.

*Sutton, John R. 2013. "The Transformation of Prison Regimes in Late Capitalist Societies." American Journal of Sociology 119(3):715-746.

*Taghizadeh, Jonas Larsson. 2014. "Quality over Quantity? Technical Information, Interest Advocacy and School Closures in Sweden.” Interest Groups \& Advocacy 4(1):1-19. *Uba, Katrin. 2005. "Political Protest and Policy Change: The Direct Impacts of Indian AntiPrivatization Mobilizations, 1990-2003.” Mobilization 10(3):383-396.

Uba, Katrin. 2009. “The Contextual Dependence of Movement Outcomes: A Simplified MetaAnalysis." Mobilization 14:433-48.

*Vasi, Ion Bogdan. 2007. “Thinking Globally, Planning Nationally, and Acting Locally.” Social Forces 86(1):113-136.

*Vasi, Ion Bogdan and David Strang. 2009. "Civil Liberty in America: the Diffusion of Municipal Bill of Rights Resolutions after the Passage of the USA PATRIOT Act.” American Journal of Sociology 114:1716-1764.

*Velasco, Kristopher. 2018. "Human Rights INGOs, LGBT INGOs, and LGBT Policy Diffusion, 1991-2015." Social Forces 97(1):377-404. 
Ziliak, Stephen T., and Deirdre N. McCloskey. 2008. The Cult of Statistical Significance: How the Standard Error Costs Us Jobs, Justice, and Lives. Ann Arbor, Michigan: University of Michigan Press.

*Zylan, Yvonne, and Sarah A. Soule. 2000. "Ending Welfare As We Know It (Again): Welfare State Retrenchment, 1989-1995.” Social Forces 79(2): 623-652. 
Table 1. The Impact of Advocacy

\begin{tabular}{lcc}
\hline Impact & Coefficients & $\%$ \\
\hline None (not predicted), wrong sign & 177 & 54 \\
None, as predicted & 15 & 5 \\
Statistically significant at .05, not discussed & 109 & 33 \\
Significant, impact discussed, not evaluated & 13 & 4 \\
Significant, little policy impact & 3 & 1 \\
Significant, considerable policy impact & 13 & 4 \\
Total & 330 & 101 \\
\hline
\end{tabular}


Table 2. High-Activity Issues and the Likelihood of Advocacy Impact

\begin{tabular}{lcc}
\hline Activity on Issue & N of coefficients & \% Significant \\
& 130 & 45 \\
Lower & 40 & 40 \\
Varying-many issues ${ }^{\mathrm{a}}$ & 145 & 43 \\
Higher & 315 & \\
\hline
\end{tabular}

${ }^{a} A$ population of issues (e.g., all bills considered), random sample, or very large number of varying importance.

Cases in which no relationship was found, as predicted, excluded; $\mathrm{N}=15$

Chi-square $=.37$, not statistically significant. 
Table 3. Impact of Advocacy by Polity

\begin{tabular}{lcc}
\hline Polity & N of coefficients & \% Significant Impact \\
U.S. federal & 58 & 48 \\
U.S. states & 119 & 39 \\
U.S. counties, municipalities & 48 & 48 \\
OECD/EU & 50 & 38 \\
Other & 40 & 55 \\
Total & 315 & \\
\hline
\end{tabular}

Cases in which no relationship was found, as predicted, excluded; $\mathrm{N}=15$

Chi-square $=4.80$, not significant at .05 . 
Table 4. Impact of Advocacy on Policy, within Measures of Policy

Percent of coefficients that are statistically significant ( $\mathrm{N}$ in parentheses)

\begin{tabular}{|c|c|c|c|c|c|}
\hline $\begin{array}{l}\text { Measure of } \\
\text { policy }\end{array}$ & $\begin{array}{r}\text { Combined } \\
\text { measures }\end{array}$ & $\begin{array}{c}\text { Specific } \\
\text { proposals, } \\
\text { multiple } \\
\text { domains }\end{array}$ & $\begin{array}{r}\text { Multiple } \\
\text { proposals, } \\
\text { same } \\
\text { domain }\end{array}$ & $\begin{array}{l}\text { Specific } \\
\text { policy } \\
\text { proposals }\end{array}$ & $\mathrm{N}$ \\
\hline $\begin{array}{l}\text { Measure of } \\
\text { advocacy }\end{array}$ & & & & & \\
\hline Resources & $52 \%(44)$ & $52 \%(29)$ & $49 \%(24)$ & $39 \%$ (119) & 216 \\
\hline $\begin{array}{l}\text { Advocacy, same } \\
\text { domain }\end{array}$ & $33 \%(9)$ & 0 & $38 \%(16)$ & $50 \%(6)$ & 31 \\
\hline $\begin{array}{l}\text { Advocacy, } \\
\text { specific proposal }\end{array}$ & $100 \%(1)$ & $7 \%(15)$ & $50 \%(4)$ & $54 \%(48)$ & 68 \\
\hline Total & 54 & 44 & 44 & 173 & 315 \\
\hline
\end{tabular}

Chi-square for advocacy and impact, controlling for measure of policy, $16.06, p=.04$.

Chi-square for measure of policy and impact, controlling for advocacy, $=17.56, \mathrm{p}=.04$.

Three-way chi-square $=85.34, \mathrm{p}<.0001$. 
Table 5. Status Quo Bias

\begin{tabular}{lccc}
\hline Advocacy & Against Change & For Change & Total \\
\hline Impact & & & \\
No impact & $50 \%$ & $54 \%$ & 156 \\
Impact & $50 \%$ & $46 \%$ & 136 \\
Total & 54 & 238 & $292^{\mathrm{a}}$ \\
\hline
\end{tabular}

a292 coefficients pertained to settings in which one side favored the status quo, and the other, change. 38 pertained to settings in which there was some other form of conflict, such as both sides favoring change (in opposite directions).

Chi-squared $=.31$, not statistically significant. 
Table 6. Impact of advocacy on policy, when public opinion is and is not included ( $\mathrm{N}$ of coefficients in parentheses)

\begin{tabular}{|c|c|c|c|}
\hline & $\begin{array}{l}\text { Public opinion not } \\
\text { included in analysis }\end{array}$ & $\begin{array}{r}\text { Public opinion } \\
\text { included }\end{array}$ & Total \\
\hline $\begin{array}{l}\text { No impact, as } \\
\text { predicted }\end{array}$ & $3 \%(7)$ & $12 \%(8)$ & 15 \\
\hline $\begin{array}{l}\text { No impact (not } \\
\text { predicted) }\end{array}$ & $56 \%(147)$ & $44 \%(30)$ & 177 \\
\hline Impact & $41 \%(108)$ & $44 \%(30)$ & 138 \\
\hline Total & 262 & 68 & 330 \\
\hline
\end{tabular}

Chi-square $=11.4$, significant at .05 . 